\title{
Characteristics of Water-soluble Inorganic lons in Aerosol and Precipitation and their Scavenging Ratios in an Urban Environment in Southwest China
}

\author{
Chuanjie Lin ${ }^{1}$, Tingting Huo ${ }^{1}$, Fumo Yang ${ }^{2}$, Bin Wang ${ }^{1}$, Yang Chen ${ }^{3}$, \\ Huanbo Wang ${ }^{1^{*}}$ \\ ${ }^{1}$ School of Environment and Resource, Southwest University of Science and Technology, \\ Mianyang 621010, China \\ ${ }^{2}$ National Engineering Research Center for Flue Gas Desulfurization, Department of \\ Environmental Science and Engineering, Sichuan University, Chengdu 610065, China \\ ${ }^{3}$ Chongqing Institute of Green and Intelligent Technology, Chinese Academy of Sciences, \\ Chongqing 400714, China
}

\section{ABSTRACT}

Daily fine particulate matter $\left(\mathrm{PM}_{2.5}\right)$ and precipitation samples were collected simultaneously at an urban site in southwest China in four segregated months in 2015 for measuring major water-soluble inorganic ions (WSIIs). Online hourly concentrations of $\mathrm{PM}_{10}$ and $\mathrm{PM}_{2.5}$ were also monitored, which showed annual mean concentrations of 67.8 and $41.6 \mu \mathrm{g} \mathrm{m}^{-3}$, respectively. $\mathrm{PM}_{2.5}$ showed the highest concentration in winter and lowest in summer. The annual mean concentration of the total WSIls was $20.3 \mu \mathrm{g} \mathrm{m}^{-3}$, accounting for about $48.7 \%$ of $\mathrm{PM}_{2.5}$. Among the total WSIls in ambient $\mathrm{PM}_{2.5}, \mathrm{SO}_{4}{ }^{2-}$ was the predominant component $(49.7 \%)$, followed by $\mathrm{NH}_{4}{ }^{+}$(24.1\%) and $\mathrm{NO}_{3}{ }^{-}$(21.4\%). $\mathrm{NH}_{4}{ }^{+}$and $\mathrm{SO}_{4}{ }^{2-}$ were the two most abundant ions in precipitation, followed by $\mathrm{Ca}^{2+}$ and $\mathrm{NO}_{3}{ }^{-}$. Seasonal patterns of the major inorganic ions in precipitation were similar to those in $\mathrm{PM}_{2.5}$, with the highest concentration in winter and lowest in summer. The mean scavenging ratios were 454, 445,364, 456, and 394 for $\mathrm{SO}_{4}{ }^{2-}, \mathrm{NO}_{3}{ }^{-}, \mathrm{NH}_{4}{ }^{+}, \mathrm{Cl}^{-}$, and $\mathrm{K}^{+}$, and 116,353 , and 18 for gas $\mathrm{SO}_{2}, \mathrm{HNO}_{3}$, and $\mathrm{NH}_{3}$, respectively. The higher scavenging ratios of

\section{OPEN ACCESS}

Received: August 9, 2020

Revised: December 8, 2020

Accepted: December 8, 2020

${ }^{*}$ Corresponding Author:

hbwang@swust.edu.cn

\section{Publisher:}

Taiwan Association for Aerosol Research

ISSN: $1680-8584$ print

ISSN: 2071-1409 online

(c) Copyright: The Author(s). This is an open access article distributed under the terms of the Creative Commons Attribution License (CC BY 4.0), which permits unrestricted use, distribution, and reproduction in any medium, provided the original author and source are cited. particulate ions than their gaseous precursors suggest the higher contributions of particles than gases to the total wet deposition.

Keywords: Wet scavenging, Water-soluble inorganic ions, $\mathrm{PM}_{2.5}$, Precipitation chemistry

\section{INTRODUCTION}

Wet scavenging efficiently removes particulate matter and their gaseous precursors from the atmosphere (Wang et al., 2018a). In-cloud (rainout) and below-cloud (washout) scavenging are the two components of wet scavenging processes for air pollutants. For particulate matter, rainout and washout mechanisms are different, with rainout involving mostly nucleation of aerosols (acting as cloud condensation nuclei) and to a much less extent impaction scavenging, whereas washout involving mainly impaction scavenging (collected by falling raindrops) (Zhang and Vet, 2006). For gases, dissolution in liquid water droplets is the mechanism for both rainout and washout processes. The relative contributions of rainout and washout to the total wet deposition could be estimated based on the sequential precipitation sampling measurements (Aikawa and Hiraki, 2009). For example, using this method, Xu et al. (2017) estimated that washout contributed about $56 \%, 61 \%$, and $47 \%$ to total wet scavenging of $\mathrm{SO}_{4}{ }^{2-}, \mathrm{NO}_{3}{ }^{-}$, and $\mathrm{NH}_{4}{ }^{+}$respectively, in Beijing, and Ge et al. (2016) obtained 88\%, 92\%, and $84 \%$ in Dalian and 56\%, 50\%, and $46 \%$ in Dandong in North China. Furthermore, washout accounted for about two-thirds of total wet scavenging for $\mathrm{NO}_{3}{ }^{-}$ and half for $\mathrm{SO}_{4}{ }^{2-}$ in Japan using the same method (Aikawa et al., 2014; Kajino and Aikawa, 2015). 
Scavenging ratio $(\mathrm{W})$, defined as the ratio of a pollutant concentration in precipitation to that in air, can be a useful indicator for wet scavenging efficiency (Engelmann, 1971). This parameter depends on the physical and chemical characteristics of both particles and precipitation, and can vary by up to two orders of magnitude with different chemical species. Budhavant et al. (2020) estimated the scavenging ratios of ten major chemical species in $\mathrm{PM}_{10}$ over the Northern Indian Ocean, and obtained values of less than 50 for black carbon and up to 3000 for $\mathrm{Cl}^{-}$and $\mathrm{NO}_{3}{ }^{-}$. Cheng and Zhang (2017) investigated the scavenging ratios of eight inorganic ions at 13 monitoring sites across Canada and obtained values varying by a factor of up to 6 , with larger values for chemical species with higher fractions in coarse particles, e.g., $\mathrm{Ca}^{2+}$ and $\mathrm{NO}_{3}{ }^{-}$. The important role that below-cloud scavenging plays on ambient aerosol concentration under different rain conditions has also been demonstrated by field experiments and numerical studies (Zhang et al., 2004; Gao et al., 2019; Lu et al., 2019; Luan et al., 2019).

Due to the strong dependence of scavenging ratio on the characteristics of particles and precipitation, existing database are subject of large uncertainties. Scavenging ratio obtained from parallel measurements of ambient particulate matter and precipitation chemistry over long sampling periods may reduce such uncertainties. Furthermore, it is even more complicated for wet-scavenged chemical species involving both particulate- and gaseous-phase pollutants in air, such as $\mathrm{SO}_{4}{ }^{2-}, \mathrm{NO}_{3}{ }^{-}$, and $\mathrm{NH}_{4}{ }^{+}$. Kasper-Giebl et al. (1999) estimated that 89-96\%, 4-12\%, and 49$79 \%$ of $\mathrm{SO}_{4}{ }^{2-}, \mathrm{NO}_{3}{ }^{-}$, and $\mathrm{NH}_{4}{ }^{+}$in precipitation were from the scavenging of their ambient particulatephase ions, respectively, with the rest from the gaseous pollutants $\left(\mathrm{SO}_{2}, \mathrm{HNO}_{3}\right.$, and $\left.\mathrm{NH}_{3}\right)$. Similarly, Cheng and Zhang (2017) suggested that $\mathrm{HNO}_{3}$ dominated the particulate $\mathrm{NO}_{3}{ }^{-}$in wet scavenging with a percentage contribution of about $72 \%$, whereas the contributions from particulate $\mathrm{SO}_{4}{ }^{2-}$ and $\mathrm{NH}_{4}{ }^{+}$were greater than the corresponding gas $\mathrm{SO}_{2}$ and $\mathrm{NH}_{3}$, with an average percentage contribution of $63 \%$ and $70 \%$, respectively. Comprehensive investigation on the relative contributions from gases and particles to the total wet deposition may improve the wet scavenging models of $\mathrm{SO}_{4}{ }^{2-}, \mathrm{NO}_{3}{ }^{-}$, and $\mathrm{NH}_{4}{ }^{+}$, and consequently reduce the uncertainties in prediction of particle concentrations during precipitation periods.

Wanzhou is a small urban city, situated in southwest China. The climate in Wanzhou is characterized by high relative humidity, extremely low wind speeds all year round, and abundant rainfall with annual precipitation of about $1200 \mathrm{~mm}$. Thus, wet scavenging is expected to play an important role in removing pollutants from the atmosphere. Previous studies have focused on the dry and wet deposition fluxes of nitrogen or other pollutants in southwest China (Wang et al., 2016; Wang et al., 2018a), but provided no information on the wet scavenging processes or scavenging ratios of water-soluble inorganic ions. The present study aims to fill this knowledge gap by simultaneously measuring $\mathrm{PM}_{2.5}$ and precipitation chemistry in different seasons of a year. The main objectives are to (1) investigate the dynamic characteristics of $\mathrm{PM}_{2.5}$ and $\mathrm{PM}_{10}$ during rainfall processes, (2) characterize major water-soluble inorganic ions in $\mathrm{PM}_{2.5}$ and precipitation, and (3) estimate the scavenging ratios of major inorganic ions and gaseous precursors as well as their relative contributions.

\section{METHODS}

\subsection{Sampling and Chemical Analysis}

$\mathrm{PM}_{2.5}$ and precipitation samples were collected in parallel in Wanzhou. The sampling site is located on the roof of a building inside the Chongqing Three Gorges University $\left(108^{\circ} 13^{\prime} \mathrm{E}\right.$, $30^{\circ} 48^{\prime} \mathrm{N}$ ), about $28 \mathrm{~m}$ above the ground, which is influenced by local vehicular emission and point sources (Wang et al., 2016). 23-h PM2.5 samples were collected by an air pollutant sampler (URG Corp., URG-3000K, North Carolina, USA) from 11:00 a.m. to 10:00 a.m. the next day at a flow rate of $15 \mathrm{~L} \mathrm{~min}^{-1}$. Two channels of the air pollutant sampler were used to collect $\mathrm{PM}_{2.5}$ samples in parallel. The left channel was preceded by two annual denuders coated with glycerol/ $\mathrm{Na}_{2} \mathrm{CO}_{3}$ and glycerol/citric acid solution for trapping $\mathrm{HNO}_{3}$ and $\mathrm{NH}_{3}$ sequentially, and then a Teflon filter was equipped for mass weighting. The right channel was loaded with quartz filter for water-soluble inorganic ions analysis. Daily precipitation samples were collected using an automatic atmospheric deposition sampler equipped with a rain gauge sensor (APS-3A, Xianglan Scientific Instruments Co., Ltd., China). Wanzhou has a subtropical monsoon climate with temperature above $0^{\circ} \mathrm{C}$ all 
year round, hence, precipitation at this location is almost always in rain. Although rainfall samples were collected on a daily basis in order to match $\mathrm{PM}_{2.5}$ sampling campaign, the rain gauge sensor could automatically record the detailed information of each rainfall event, including the beginning and ending time, besides the rainfall amount. Sampling campaigns were conducted in four months in 2015: from $2^{\text {nd }}$ to $29^{\text {th }}$ in April, $2^{\text {th }}$ to $30^{\text {th }}$ in July, $16^{\text {th }}$ October to $13^{\text {th }}$ November, $16^{\text {th }}$ December to $14^{\text {th }}$ January in 2016, representing spring, summer, autumn, and winter, respectively. Note that $\mathrm{PM}_{2.5}$ samples were not available from $2^{\text {nd }}$ to $7^{\text {th }}$ July due to the sampler maintenance. $\mathrm{PM}_{2.5}$ samples were stored in the dark and at $-18^{\circ} \mathrm{C}$ until analysis to prevent the evaporation of volatile compounds, while rainfall samples were filtered through a $0.45 \mu \mathrm{m}$ filter after collection and refrigerated at $4^{\circ} \mathrm{C}$.

Five cations $\left(\mathrm{Na}^{+}, \mathrm{NH}_{4}{ }^{+}, \mathrm{K}^{+}, \mathrm{Mg}^{2+}, \mathrm{Ca}^{2+}\right)$ and three anions $\left(\mathrm{Cl}^{-}, \mathrm{SO}_{4}{ }^{2-}, \mathrm{NO}_{3}{ }^{-}\right)$were determined by an ion chromatography (DX-600, Dionex, Sunnyvale, CA) for both $\mathrm{PM}_{2.5}$ and rainfall samples. Cations were measured using a CS12A column with $20 \mathrm{mM}$ methanesulfonic acid (MSA) as an eluent while anions were analyzed using an AS11- $\mathrm{HC}$ column with $30 \mathrm{mM} \mathrm{KOH}$ as an eluent. lons in rainfall samples were measured directly, while $\mathrm{PM}_{2.5}$ samples should be extracted using ultrapure water before ion chromatography analysis. $\mathrm{HNO}_{3}$ and $\mathrm{NH}_{3}$ captured by denuders were extracted using ultrapure water first, and then measured by an ion chromatography. A detailed description of $\mathrm{PM}_{2.5}$ and rainfall sampling as well as water-soluble inorganic ions analysis were presented in Wang et al. $\left(2016,2018\right.$ b). For $\mathrm{Na}^{+}$in $\mathrm{PM}_{2.5}$, the field blanks varied largely and might result in large uncertainties. For $\mathrm{Mg}^{2+}$ and $\mathrm{Ca}^{2+}$, most of $\mathrm{PM}_{2.5}$ samples were below the detection limits due to their relatively low concentrations. Hence, only five water-soluble inorganic ions in $\mathrm{PM}_{2.5}$ including $\mathrm{SO}_{4}{ }^{2-}, \mathrm{NO}_{3}{ }^{-}, \mathrm{NH}_{4}{ }^{+}, \mathrm{Cl}^{-}$, and $\mathrm{K}^{+}$were discussed in the following section.

Hourly concentrations of $\mathrm{PM}_{2.5}$ and $\mathrm{PM}_{10}$ were measured using online $\mathrm{PM}_{2.5} / \mathrm{PM}_{10}$ analyzer (FH62C14, Thermo Fisher, U.S.). Hourly concentrations of $\mathrm{SO}_{2}$ were not available at the sampling site and obtained from an air quality monitoring station about $6 \mathrm{~km}$ away.

\subsection{Data Analysis}

The rate of change in particle concentration $(\Delta C)$ for each rainfall event was defined as follows:

$\Delta C(\%)=\frac{\left(C_{b}-C_{d}\right)}{C_{b}} \times 100 \%$

where $C_{b}$ is the average concentration of $\mathrm{PM}_{2.5}$ or $\mathrm{PM}_{10}$ within $3 \mathrm{~h}$ before the rain, $C_{d}$ is the average concentration during the rain. If the value of $\Delta C$ is positive, it means that $\mathrm{PM}_{2.5}$ or $\mathrm{PM}_{10}$ decreases when rainfall occurs, otherwise, it indicates that $\mathrm{PM}_{2.5}$ or $\mathrm{PM}_{10}$ increases during rain. Calculation of $\Delta C$ requires that the free-rainfall period between two events is higher than $3 \mathrm{~h}$, otherwise, consecutive rainfall events are combined (Aikawa et al., 2014). As a consequence, a total of $7,8,14$, and 13 rainfall events were obtained in spring, summer, autumn, and winter, respectively (Table $\mathrm{S} 1$ ).

Scavenging ratio of major inorganic ions in each month was calculated based on monthly mean concentration as follows (Kasper-Giebl et al., 1999; Cheng and Zhang, 2017):

$W=\frac{C_{\text {prec }}}{C_{\text {air }}} \times \frac{\rho_{a}}{\rho_{w}}$

where $C_{\text {prec }}$ is the volume weighted mean (VWM) concentration of inorganic ions in precipitation $\left(\mathrm{mg} \mathrm{L}^{-1}\right), C_{\text {air }}$ is the mean concentration of water-soluble inorganic ions in the air $\left(\mu \mathrm{g} \mathrm{m}^{-3}\right)$, and $\rho_{a}$ and $\rho_{\mathrm{w}}$ are the density of air $\left(1200 \mathrm{~g} \mathrm{~m}^{-3}\right)$ and water, respectively.

$\mathrm{SO}_{4}{ }^{2-}, \mathrm{NO}_{3}{ }^{-}$, and $\mathrm{NH}_{4}{ }^{+}$in rainfall originated from both particles and gaseous precursors. Hence, it is assumed that the difference between the total and particulate wet scavenging was from the gaseous precursor. Scavenging ratio of gaseous precursor was calculated followed by Cheng and Zhang (2017). The procedure for estimating the scavenging ratio of $\mathrm{HNO}_{3}$ was described in detail, and the calculation for the scavenging ratio of $\mathrm{SO}_{2}$ and $\mathrm{NH}_{3}$ was done similarly.

The particulate $\mathrm{NO}_{3}{ }^{-}$concentration in rainfall was first estimated as follows: 
where $\left[\mathrm{pNO}_{3}{ }^{-}\right.$]prec is the part of $\mathrm{NO}_{3}{ }^{-}$wet scavenging from particulate $\mathrm{NO}_{3}{ }^{-} . \mathrm{W}_{\text {fPM }}$ and $\mathrm{W}_{\mathrm{CPM}}$ are monthly scavenging ratio of fine and coarse particles, respectively. $W_{\text {fPM }}$ could be calculated from the scavenging ratio of $\mathrm{K}^{+}$, while $\mathrm{W}_{\mathrm{CPM}}$ could be calculated based on the average scavenging ratio of $\mathrm{Ca}^{2+}, \mathrm{Mg}^{2+}$, and $\mathrm{Na}^{+}$. In this study, the coarse particles data were not available, thus the contributions from coarse particles were neglected. [ $\left.\mathrm{pNO}_{3}{ }^{-}\right]_{\mathrm{fPM}}$ and $\left[\mathrm{pNO}_{3}{ }^{-}\right]_{\mathrm{CPM}}$ are monthly mean concentration of $\mathrm{NO}_{3}{ }^{-}$in fine and coarse particles, respectively. Note that the concentrations of major inorganic ions in coarse particles were not available, alternative data assumptions were made, which were discussed in the following section in detail. Then, the scavenging ratio of $\mathrm{HNO}_{3}$ and its contribution were calculated as follows:

$\left[\mathrm{HNO}_{3}\right]_{\text {prec }}=\left[\text { total } \mathrm{NO}_{3}{ }^{-}\right]_{\text {prec }}-\left[\mathrm{pNO}_{3}{ }^{-}\right]_{\text {prec }}$

$\mathrm{W}_{\mathrm{HNO}_{3}}=\frac{\left[\mathrm{HNO}_{3}\right]_{\text {prec }}}{\left[\mathrm{HNO}_{3}\right]_{\mathrm{air}}}$

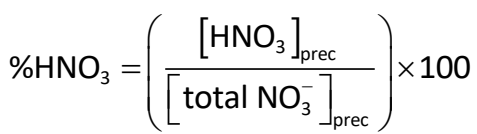

$\% \mathrm{pNO}_{3}^{-}=\left(\frac{\left[\mathrm{pNO}_{3}^{-}\right]_{\mathrm{prec}}}{\left[\text { total } \mathrm{NO}_{3}^{-}\right]_{\text {prec }}}\right) \times 100$

where [total $\left.\mathrm{NO}_{3}{ }^{-}\right]_{\text {prec }}$ means the monthly VWM concentrations of $\mathrm{NO}_{3}{ }^{-}$in rainfall, $\left[\mathrm{HNO}_{3}\right]_{\text {prec }}$ is the concentration of $\mathrm{NO}_{3}{ }^{-}$in rainfall from gas contribution, and $\left[\mathrm{HNO}_{3}\right]_{\text {air }}$ is ambient concentration of gas $\mathrm{HNO}_{3} . \% \mathrm{HNO}_{3}$ and $\% \mathrm{NO}_{3}{ }^{-}$are the contributions of $\mathrm{HNO}_{3}$ and particulate $\mathrm{NO}_{3}{ }^{-}$to the total $\mathrm{NO}_{3}{ }^{-}$wet scavenging, respectively. In some cases, the calculated $\left[\mathrm{HNO}_{3}\right]_{\text {prec }}$ value was negative, then we assumed that only particulate $\mathrm{NO}_{3}{ }^{-}$contributed to the wet scavenging and the contribution from gas $\mathrm{HNO}_{3}$ was negligible.

\section{RESULTS AND DISCUSSION}

\subsection{Variations of Hourly Particulate Matter Concentrations during Rain Events}

During the observation periods, the accumulated rainfall amounts were 79.2, 152.8, 85.8, and $31.7 \mathrm{~mm}$ in spring, summer, autumn, and winter, respectively, while the corresponding total rainfall hours were $57.1,61.7,38.2$, and $53.3 \mathrm{~h}$. Note that the rainfall data were obtained in a typical month rather than three months in each season. In Wanzhou, rainfall was the most abundant in summer and least in winter. Although the total rainfall hours were similar in spring, summer, and winter, the accumulated amounts varied about five times due to the different rainfall intensities. Rain could be classified into three categories based on the rainfall intensity (Luan et al., 2019): light rain $\left(0.1-2.5 \mathrm{~mm} \mathrm{~h}^{-1}\right)$, moderate rain $\left(2.6-7.6 \mathrm{~mm} \mathrm{~h}^{-1}\right.$ ), and heavy rain $\left(>7.6 \mathrm{~mm} \mathrm{~h}^{-1}\right.$ ). Regarding the rain events recorded by rain gauge sensor, the predominant rain category was light rain in all seasons, in particular in spring and winter where the numbers of light rain events accounted for about $96 \%$ and $100 \%$ of the total events, respectively. Moderate and heavy rain events contributed to about $15.8 \%$ and $17.9 \%$ of the total events in summer, and $5.3 \%$ and $3.6 \%$ in autumn, respectively.

Particulate matter concentrations were affected by many factors, such as source emissions and wet scavenging effects. Fig. 1 shows the hourly concentrations of $\mathrm{PM}_{2.5}, \mathrm{PM}_{10}$, and rain intensities during the observation periods. For those rainfall events with relatively long durations and/or high rainfall intensities, $\mathrm{PM}_{2.5}$ and $\mathrm{PM}_{10}$ concentrations decreased greatly during rain, e.g., on $19^{\text {th }}$ April, $15^{\text {th }}$ July, and $25^{\text {th }}$ October in 2015 , and $7^{\text {th }}$ January 2016 , indicating that wet scavenging 

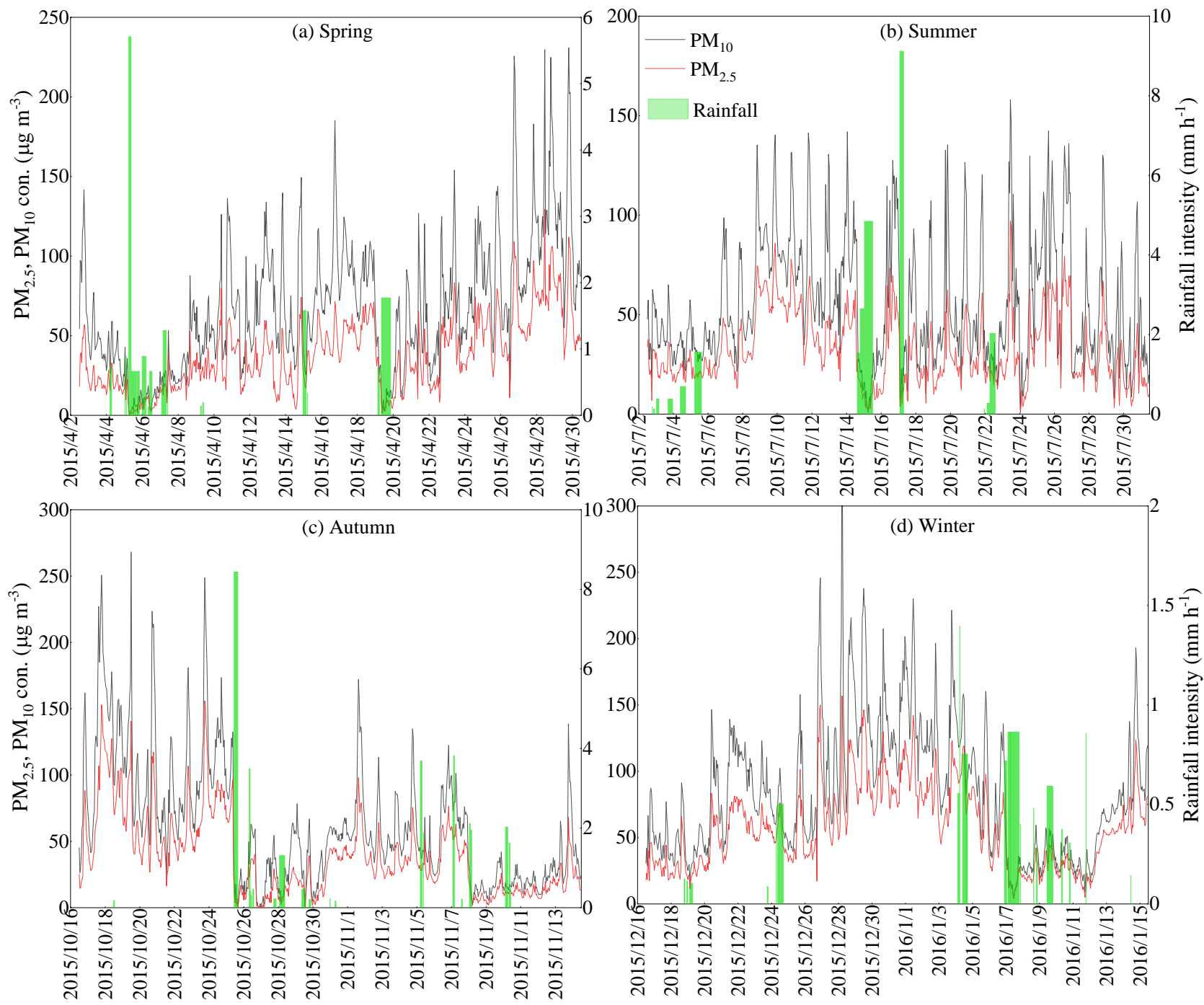

Fig. 1. Hourly concentrations of $\mathrm{PM}_{2.5}, \mathrm{PM}_{10}$, and rainfall intensity in spring, summer, autumn, and winter.

played an important role on the decreases of the $\mathrm{PM}_{2.5}$ and $\mathrm{PM}_{10}$ concentrations. However, for those rainfall events with short durations or low intensities, the scavenging effects exhibited large variations, implying that other factors would primarily contribute to the variations of particle concentrations. For example, on $21^{\text {st }}$ July with the rain duration of $0.8 \mathrm{~h}$ and rain intensity of $0.13 \mathrm{~mm} \mathrm{~h}^{-1}, \mathrm{PM}_{2.5}$ and $\mathrm{PM}_{10}$ concentrations decreased by $39 \%$ and $48 \%$ during rain, respectively. We found that this phenomenon was caused by the increased $\mathrm{PM}_{2.5}$ and $\mathrm{PM}_{10}$ concentrations during the rush hours in the evening, and when the rush hours ended after 21:00 local time, the air pollutants concentrations began to decrease. This can be supported by the increased $\mathrm{NO}_{2}$ concentrations during the rush hours and the decreased concentrations one or two hours before the rain. That means the decreases of $\mathrm{PM}_{2.5}$ and $\mathrm{PM}_{10}$ concentrations on this day were ascribed to the emission reduction after rush hours rather than the wet scavenging effects. On $24^{\text {th }}$ December, $\mathrm{PM}_{2.5}$ and $\mathrm{PM}_{10}$ concentrations increased by about $27 \%$ during rain period although it lasted about 8 hours from 7:00 to 17:00 local time. The reason for this phenomenon was similar to the rain event on $21^{\text {st }} \mathrm{July}$, which was caused by the high emissions during the rush hours when rain occurred, resulting in relatively high average $\mathrm{PM}_{2.5}$ and $\mathrm{PM}_{10}$ concentrations. Furthermore, no evident variations of $\mathrm{PM}_{2.5}$ and $\mathrm{PM}_{10}$ concentrations were observed before and during rain on $7^{\text {th }}$ April, in which the duration was about $5 \mathrm{~h}$ and rainfall intensity was greater than $1.0 \mathrm{~mm} \mathrm{~h}^{-1}$. In total, those distinct scavenging effects for different rainfall events indicated that other factors also affected the overall scavenging effects besides rainfall duration and intensities. 
The variations of $\mathrm{PM}_{2.5}$ and $\mathrm{PM}_{10}$ concentrations were not uniform for each event, showing increasing or decreasing trends when rainfall occurred (Fig. 2). For $\mathrm{PM}_{10}$, almost all events showed decreasing trends in spring. In other seasons, the number of events with decreasing trends accounted for about $62.5-71.4 \%$ of the total rain events. For $\mathrm{PM}_{2.5}$, the number of events presenting decreasing trends accounted for $50-64.3 \%$ of the total rainfall events, implying the important role of wet scavenging effects on decreasing particle concentrations.

Generally, the decreasing rates of $\mathrm{PM}_{10}$ by rainfall were higher than $\mathrm{PM}_{2.5}$ for every event (Fig. 2), which can be explained by the size-dependent below-cloud impaction scavenging efficiency (Wang et al., 2010). Besides particle size distribution, removal rates are also related to the concentrations of particles before rain. The rates of change in particle concentrations were grouped with $\mathrm{PM}_{10}$ or $\mathrm{PM}_{2.5}$ concentrations before rain at $20 \mu \mathrm{g} \mathrm{m}^{-3}$ interval bins. As shown in Fig. 3(a), $\Delta C$ typically increased with the increases of $P M_{10}$ and $P M_{2.5}$ concentrations, and the highest change rate in $\mathrm{PM}_{10}$ and $\mathrm{PM}_{2.5}$ concentrations appeared in the range of $80-100 \mu \mathrm{g} \mathrm{m}^{-3}$ and $60-80 \mu \mathrm{g} \mathrm{m}^{-3}$, respectively. This trend was also observed by Olszowski (2016), in which the scavenging effect was well correlated with higher particle concentrations before rain. Note that $\Delta C$ showed decreasing trends when $\mathrm{PM}_{10}$ and $\mathrm{PM}_{2.5}$ concentrations were higher than $100 \mu \mathrm{g} \mathrm{m}^{-3}$. This phenomenon indicated that other meteorological conditions might govern the severe $\mathrm{PM}_{10}$ and $\mathrm{PM}_{2.5}$ pollution and then the wet scavenging effect was overwhelmed.

It has been reported that the rainfall intensity also influenced the variations of particle concentrations (He and Balasubramanian, 2008; Luan et al., 2019). As shown in Fig. 3(b), $\Delta C$ was highest (higher than $50 \%$ for both $\mathrm{PM}_{10}$ and $\mathrm{PM}_{2.5}$ ) when rainfall intensities were higher than $2 \mathrm{~mm} \mathrm{~h}^{-1}$, indicating that moderate or heavy rain exhibited relatively high scavenging efficiency on particulate matter. This can also be explained by the precipitation-intensity dependent belowcloud scavenging efficiency (Wang et al., 2010). Scavenging effects were positive for each moderate or heavy rainfall event with the value of $\Delta C$ in the range of $8.3-90.9 \%$ for $\mathrm{PM}_{10}$ and 2.6-93.5\% for $\mathrm{PM}_{2.5}$, respectively. However, no obvious trends of $\Delta C$ were observed for light rains, likely because other factors overwhelmed the below-cloud scavenging effect.

\subsection{Gaseous Precursors and Water-soluble Inorganic lons in $\mathbf{P M}_{2.5}$ and Rainfall}

Among the three gaseous precursors discussed here, the annual mean concentrations were the lowest for $\mathrm{HNO}_{3}$, followed by $\mathrm{SO}_{2}$, and highest for $\mathrm{NH}_{3}$ (Table 1). From a seasonal perspective, $\mathrm{SO}_{2}$ showed the highest concentration in spring and lowest in summer. $\mathrm{SO}_{2}$ is primarily emitted from coal combustion for residential heating, power plants and industrial use in China. Wanzhou is located in southwest China with a temperature of above $0^{\circ} \mathrm{C}$ all year round, and residential heating using coal may not be extensive in this region. Thus, the seasonal patterns of $\mathrm{SO}_{2}$ were

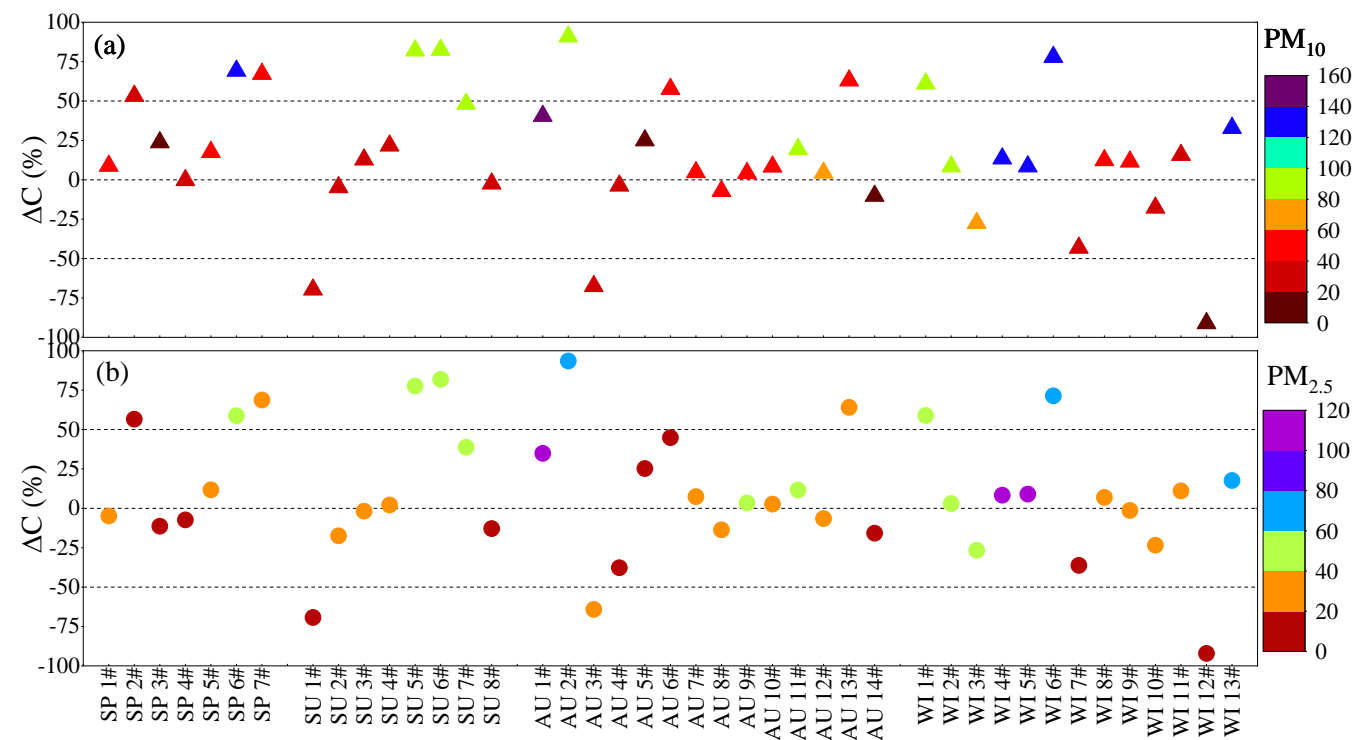

Fig. 2. The variations of $\mathrm{PM}_{10}(\mathrm{a})$ and $\mathrm{PM}_{2.5}$ (b) concentrations for each rainfall event. 

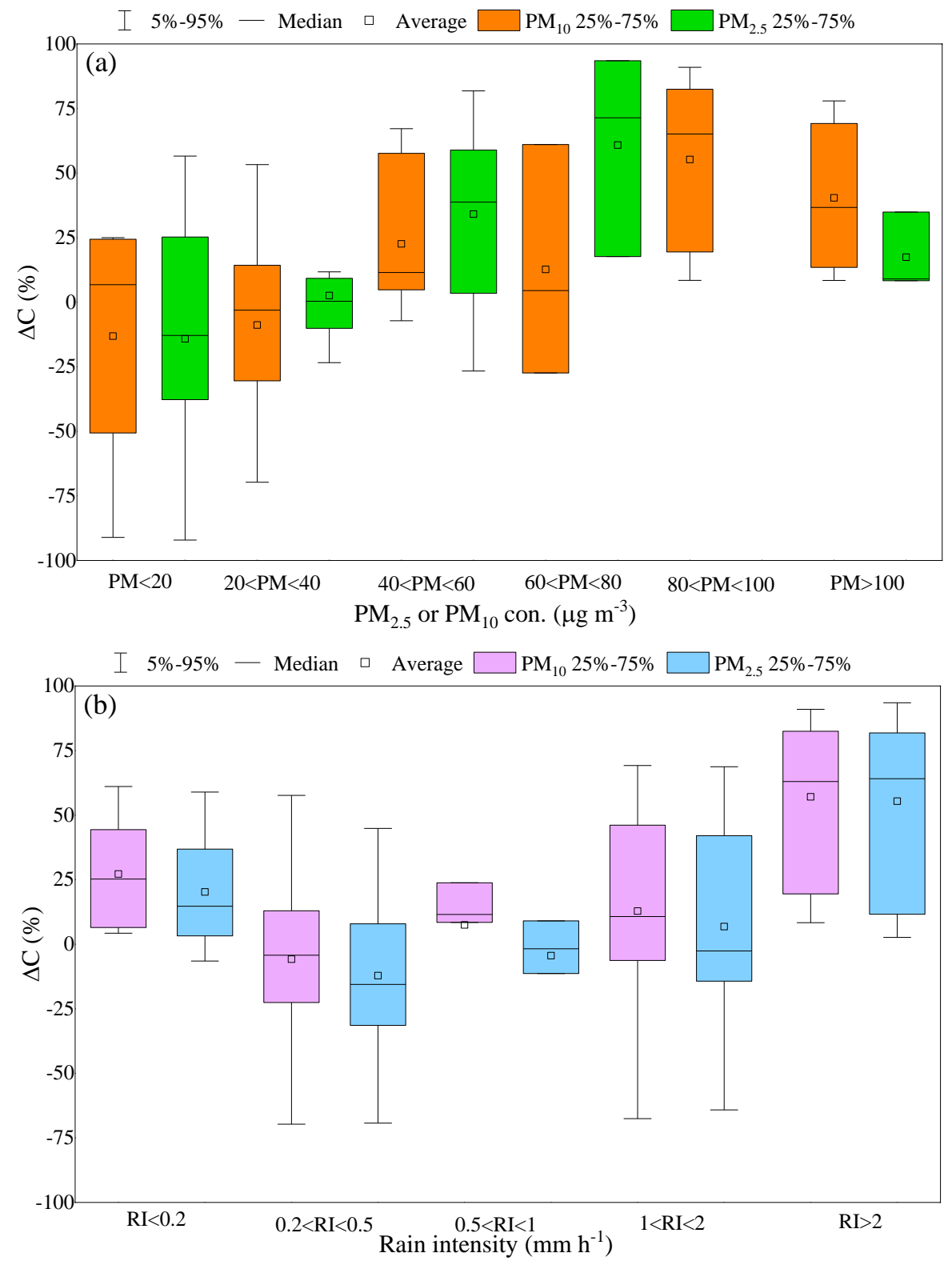

Fig. 3. The variations of $\mathrm{PM}_{10}$ and $\mathrm{PM}_{2.5}$ grouped by particle concentrations before rain (a), and rain intensity bins (b).

Table 1. Seasonal and annual concentrations of gaseous precursors and major inorganic ions in $\mathrm{PM}_{2.5}$ and precipitation.

\begin{tabular}{|c|c|c|c|c|c|c|c|c|c|c|c|c|c|}
\hline & \multicolumn{5}{|c|}{$\ln \mathrm{PM}_{2.5}\left(\mu \mathrm{g} \mathrm{m}^{-3}\right)$} & \multicolumn{8}{|c|}{ In precipitation $\left(\mu \mathrm{eq} \mathrm{L}^{-1}\right)$} \\
\hline & $\mathrm{Cl}^{-}$ & $\mathrm{SO}_{4}{ }^{2-}$ & $\mathrm{NO}_{3}^{-}$ & $\mathrm{NH}_{4}^{+}$ & $\mathrm{K}^{+}$ & $\mathrm{Cl}^{-}$ & $\mathrm{SO}_{4}{ }^{2-}$ & $\mathrm{NO}_{3}^{-}$ & $\mathrm{NH}_{4}^{+}$ & $\mathrm{K}^{+}$ & $\mathrm{Ca}^{2+}$ & $\mathrm{Na}^{+}$ & $\mathrm{Mg}^{2+}$ \\
\hline Spring & 0.27 & 8.1 & 2.9 & 4.1 & 0.35 & 4.8 & 92.5 & 30.4 & 78.6 & 4.6 & 74.4 & 3.1 & 10.5 \\
\hline Summer & 0.05 & 8.9 & 1.3 & 3.4 & 0.23 & 4.2 & 50.3 & 19.1 & 70.1 & 1.7 & 29.3 & 2.9 & 4.3 \\
\hline Autumn & 0.59 & 7.5 & 3.7 & 3.9 & 0.41 & 6.7 & 116.6 & 33.8 & 104.6 & 4.9 & 104.9 & 54.7 & 8.8 \\
\hline Winter & 1.3 & 15.4 & 8.6 & 7.7 & 0.58 & 23.0 & 146.0 & 51.3 & 103.6 & 6.1 & 76.3 & 12.1 & 15.1 \\
\hline \multirow[t]{2}{*}{ Annual } & 0.59 & 10.1 & 4.3 & 4.9 & 0.40 & 6.3 & 79.4 & 25.9 & 82.2 & 3.4 & 54.6 & 13.6 & 7.1 \\
\hline & \multicolumn{4}{|c|}{$\mathrm{SO}_{2}\left(\mu \mathrm{g} \mathrm{m}^{-3}\right)$} & \multicolumn{4}{|c|}{$\mathrm{HNO}_{3}\left(\mu \mathrm{g} \mathrm{m}^{-3}\right)$} & \multicolumn{5}{|c|}{$\mathrm{NH}_{3}\left(\mu \mathrm{g} \mathrm{m}^{-3}\right)$} \\
\hline Spring & \multicolumn{4}{|l|}{14.8} & \multicolumn{4}{|l|}{1.4} & \multicolumn{5}{|l|}{14.2} \\
\hline Summer & \multicolumn{4}{|l|}{9.3} & \multicolumn{4}{|l|}{2.8} & \multicolumn{5}{|l|}{16.3} \\
\hline Autumn & \multicolumn{4}{|l|}{11.5} & \multicolumn{4}{|l|}{1.0} & \multicolumn{5}{|l|}{14.1} \\
\hline Winter & \multicolumn{4}{|l|}{12.3} & \multicolumn{4}{|l|}{1.4} & \multicolumn{5}{|l|}{8.9} \\
\hline Annual & \multicolumn{4}{|l|}{12.0} & \multicolumn{4}{|l|}{1.6} & \multicolumn{5}{|l|}{13.1} \\
\hline
\end{tabular}


mainly influenced by the meteorological conditions and chemical transformations rather than source emissions. High temperature and strong solar radiation in summer could enhance photochemical reactions, leading to the decrease of gaseous precursor concentration such as $\mathrm{SO}_{2}$ and the increase of the secondary aerosol such as $\mathrm{SO}_{4}{ }^{2-}$. In addition, the high planetary boundary layer height in summer favors the pollutants dispersion and then leads to the low $\mathrm{SO}_{2}$ concentration. Contrary to the case of $\mathrm{SO}_{2}, \mathrm{HNO}_{3}$ and $\mathrm{NH}_{3}$ exhibited the maximum concentrations in summer and lowest values in winter and autumn, which were likely associated more with the source emission and thermodynamic behavior of $\mathrm{NH}_{4} \mathrm{NO}_{3}$ than other conditions (Wang et al., 2018b).

The annual mean concentration of $\mathrm{PM}_{2.5}$ was $41.6 \pm 24.5 \mu \mathrm{g} \mathrm{m}^{-3}$, with the highest concentration in winter and lowest in summer. The total concentration of the five major water-soluble inorganic ions (WSIIs) was $20.3 \mu \mathrm{g} \mathrm{m}^{-3}$, accounting for about $48.7 \%$ of $\mathrm{PM}_{2.5}$. All five water-soluble inorganic ions displayed the highest concentrations in winter (Fig. 4 and Table 1), which were partly related to the unfavorable diffusion conditions, i.e., extremely weak wind $\left(<1 \mathrm{~m} \mathrm{~s}^{-1}\right)$ and low precipitation amount. In addition, the relative humidity was generally higher than $80 \%$ in winter, which was conducive to secondary inorganic aerosol formation through heterogeneous reactions and thus increased the concentrations of $\mathrm{SO}_{4}{ }^{2-}, \mathrm{NO}_{3}{ }^{-}$, and $\mathrm{NH}_{4}{ }^{+}$. Biomass burning for residential heating in winter probably contributed to the higher concentrations of $\mathrm{Cl}^{-}$and $\mathrm{K}^{+}$. The lowest concentrations of the five inorganic ions appeared in summer due to the favorable diffusion conditions and abundant precipitation with the exception of $\mathrm{SO}_{4}{ }^{2-}$, which was in autumn. Furthermore, the pronounced high concentrations of $\mathrm{NO}_{3}{ }^{-}$in winter and extremely low concentrations in summer were governed by the thermodynamic equilibrium of $\mathrm{NH}_{4} \mathrm{NO}_{3}$, since the low temperature and high relative humidity in winter were conducive to the formation of particulate $\mathrm{NO}_{3}{ }^{-}$, whereas high temperature in summer enhanced the volatilization of $\mathrm{NH}_{4} \mathrm{NO}_{3}$ (Wang et al., 2018b). Compared with the other inorganic ions, the relatively higher concentration of $\mathrm{SO}_{4}{ }^{2-}$ in summer was mainly ascribed to the intense photochemical reactions as mentioned above. In $\mathrm{PM}_{2.5}$, the winter/summer ratios were 1.7, 6.7, 2.3, 25, and 2.5 for $\mathrm{SO}_{4}{ }^{2-}, \mathrm{NO}_{3}{ }^{-}, \mathrm{NH}_{4}{ }^{+}, \mathrm{Cl}^{-}$, and $\mathrm{K}^{+}$, respectively, indicating that $\mathrm{NO}_{3}{ }^{-}$and $\mathrm{Cl}^{-}$presented the largest seasonal variations.

Among the five major water-soluble inorganic ions in $\mathrm{PM}_{2.5}, \mathrm{SO}_{4}{ }^{2-}$ is the most abundant ions, showing seasonal mean contributions of $46-64 \%$ to WSIls during the sampling periods, implying the important contributions of coal combustion to $\mathrm{PM}_{2.5}$ pollution. Besides $\mathrm{SO}_{4}{ }^{2-}, \mathrm{NO}_{3}{ }^{-}$and $\mathrm{NH}_{4}{ }^{+}$ were also predominant components of WSIls. In autumn and winter, $\mathrm{NO}_{3}{ }^{-}$and $\mathrm{NH}_{4}{ }^{+}$showed comparable contributions, each of which was about half of that of $\mathrm{SO}_{4}{ }^{2-}$. However, $\mathrm{SO}_{4}{ }^{2-}, \mathrm{NO}_{3}{ }^{-}$, and $\mathrm{NH}_{4}{ }^{+}$presented distinct contributions to WSIls in summer, where the percentage of $\mathrm{SO}_{4}{ }^{2-}$ was about 3 times that of $\mathrm{NH}_{4}^{+}$and even 7 times higher than that of $\mathrm{NO}_{3}^{-}$. The relatively high contribution of $\mathrm{SO}_{4}{ }^{2-}$ and quite low contribution of $\mathrm{NO}_{3}{ }^{-}$were consistent with the patterns of their concentrations. The fractions of $\mathrm{Cl}^{-}$and $\mathrm{K}^{+}$in WSIls were minor, ranging from $0.37 \%$ in summer to $3.8 \%$ in winter for $\mathrm{Cl}^{-}$and from 1.6 to $2.6 \%$ for $\mathrm{K}^{+}$.

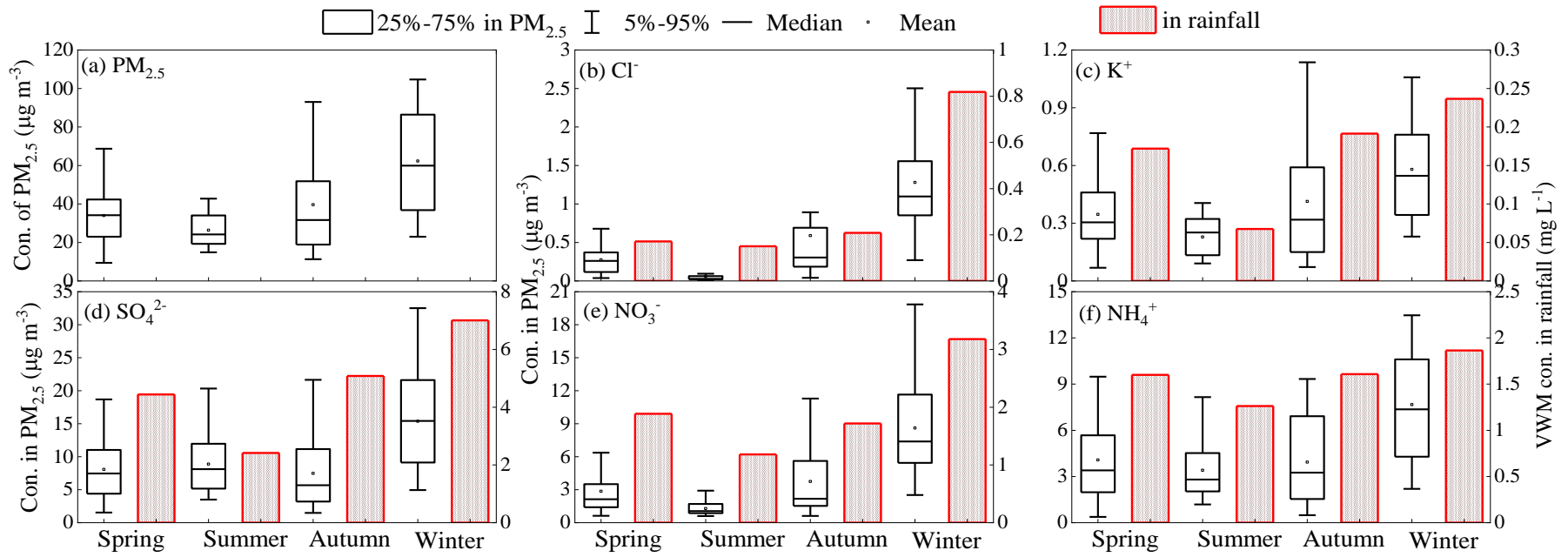

Fig. 4. Seasonal patterns of (a) $\mathrm{PM}_{2.5}$, (b) $\mathrm{Cl}^{-}$, (c) $\mathrm{K}^{+}$, (d) $\mathrm{SO}_{4}{ }^{2-}$, (e) $\mathrm{NO}_{3}{ }^{-}$, and (f) $\mathrm{NH}_{4}{ }^{+}$in $\mathrm{PM}_{2.5}$ as well as the seasonal VWM concentrations of inorganic ions in rainfall. 
As shown in Fig. 4 and Table 1, the seasonal variations of eight inorganic ions in rainfall followed the patterns of those in $\mathrm{PM}_{2.5}$, showing the highest VWM concentrations in winter and lowest in summer. Besides the relatively low concentrations of pollutants in the air, dilution effect due to the abundant rainfall was also responsible for the lower concentrations of those inorganic ions in summer. Compared the winter/summer ratios of the inorganic ions in $\mathrm{PM}_{2.5}$ and rainfall, it could be found that the seasonal variations were more pronounced in $\mathrm{PM}_{2.5}$ than in rainfall except for $\mathrm{SO}_{4}{ }^{2-}$, implying the sensitivity of the air pollutants to the meteorological conditions. Although $\mathrm{Ca}^{2+}$ concentrations were very low in $\mathrm{PM}_{2.5}$, they were almost comparable to $\mathrm{NH}_{4}{ }^{+}$in rainfall in spring and autumn, highlighting a high contribution from coarse particles to rainfall. On an equivalent amount basis, rainfall was dominated by $\mathrm{NH}_{4}{ }^{+}$and $\mathrm{SO}_{4}{ }^{2-}$, followed by $\mathrm{Ca}^{2+}$ and $\mathrm{NO}_{3}{ }^{-}$(Table 1). The distribution of inorganic ions abundance in rainfall at Wanzhou was similar to Hangzhou (Han et al., 2019), but slightly different from the mean value across China which showed $\mathrm{SO}_{4}{ }^{2-}$ and $\mathrm{Ca}^{2+}$ as the most abundant species (Li et al., 2019b).

\subsection{Scavenging Ratios of Major Inorganic lons}

Calculating scavenging ratios of inorganic ions and gaseous pollutants required more parameters, including the concentrations of major inorganic ions in fine particles, coarse particles and rainfall, and the concentrations of $\mathrm{SO}_{2}, \mathrm{HNO}_{3}$, and $\mathrm{NH}_{3}$. Fine/coarse fractions of these ions were not measured in the present study, but were previously reported for urban sites in Chongqing (Li et al., 2018a, b), which can be considered to be representative of the location of the present study. Briefly, $\mathrm{Mg}^{2+}$ and $\mathrm{Ca}^{2+}$ were mainly distributed in coarse particles, $\mathrm{SO}_{4}{ }^{2-}, \mathrm{NH}_{4}{ }^{+}$, and $\mathrm{K}^{+}$were primarily in fine particles, and $\mathrm{Na}^{+}, \mathrm{NO}_{3}{ }^{-}$, and $\mathrm{Cl}^{-}$were distributed in both fine and coarse particles (Table S2). In this study, the concentrations of inorganic ions in coarse particles were not available. Considering the relatively high fractions of coarse particles for $\mathrm{Mg}^{2+}, \mathrm{Ca}^{2+}$, and $\mathrm{Na}^{+}$, the scavenging ratios of these ions will be highly uncertain if their concentrations in coarse particles were ignored. Meanwhile, the scavenging ratio of coarse particles ( $W_{\text {CPM }}$ ) cannot be obtained due to the lack of coarse particles data, since $W_{\text {CPM }}$ was determined by averaging scavenging ratios of $\mathrm{Na}^{+}, \mathrm{Mg}^{2+}$, and $\mathrm{Ca}^{2+}$ (Cheng and Zhang, 2017). Nevertheless, it is assumed that the influences due to the lack of coarse particles data would be minor on those inorganic ions dominated in fine particles. Thus, the scavenging ratios were only analyzed for $\mathrm{SO}_{4}{ }^{2-}, \mathrm{NO}_{3}{ }^{-}, \mathrm{NH}_{4}{ }^{+}, \mathrm{Cl}^{-}$, and $\mathrm{K}^{+}$using their concentrations in $\mathrm{PM}_{2.5}$. Taking into account the fractions of $\mathrm{K}^{+}$in fine particles around $80 \%$, the scavenging ratio of $\mathrm{K}^{+}$multiplied by 0.8 was assumed to be the scavenging ratio of fine particle ( $\left.\mathrm{W}_{\mathrm{fPM}}\right)$.

Seasonal and annual mean scavenging ratios of five inorganic ions and three gases are summarized in Table 2. On an annual basis, $\mathrm{SO}_{4}{ }^{2-}, \mathrm{NO}_{3}{ }^{-}$, and $\mathrm{Cl}^{-}$showed comparable scavenging ratios at around 450, which was about $13-25 \%$ higher than the values for $\mathrm{NH}_{4}^{+}$and $\mathrm{K}^{+}$. As shown in Fig. S1, positive correlations of equivalent concentrations between $\left[\mathrm{NH}_{4}^{+}\right]$and $\left[\mathrm{SO}_{4}{ }^{2-}+\mathrm{NO}_{3}{ }^{-}\right]$ were observed in the four seasons, with the correlation coefficients higher than 0.90 and the slopes of linear regressions being around 1.0, suggesting that $\mathrm{SO}_{4}{ }^{2-}$ and $\mathrm{NO}_{3}{ }^{-}$were fully neutralized by $\mathrm{NH}_{4}{ }^{+}$, and $\left(\mathrm{NH}_{4}\right)_{2} \mathrm{SO}_{4}$ and $\mathrm{NH}_{4} \mathrm{NO}_{3}$ were the two major chemical forms in $\mathrm{PM}_{2.5}$. Consequently, it seems that $\mathrm{SO}_{4}{ }^{2-}, \mathrm{NO}_{3}{ }^{-}$, and $\mathrm{NH}_{4}{ }^{+}$should have consistent scavenging ratios due to their coexistence in fine particles. However, slightly higher values of $\mathrm{SO}_{4}{ }^{2-}$ and $\mathrm{NO}_{3}{ }^{-}$than $\mathrm{NH}_{4}{ }^{+}$were observed. As mentioned above, about $30 \%-40 \%$ of $\mathrm{Cl}^{-}$and $\mathrm{NO}_{3}{ }^{-}$were found in coarse particles, thus the relatively higher scavenging ratio of $\mathrm{NO}_{3}{ }^{-}$was in part ascribed to the contributions from coarse particles. The slightly higher scavenging ratio of $\mathrm{SO}_{4}{ }^{2-}$ was probably attributed to the in-cloud rainout process, since $\mathrm{SO}_{4}{ }^{2-}$ could be formed efficiently through in-cloud oxidation of $\mathrm{SO}_{2}$ by $\mathrm{H}_{2} \mathrm{O}_{2}$ or $\mathrm{O}_{3}$, and then the cloud droplets including $\mathrm{SO}_{4}{ }^{2-}$ could be removed as the raindrop falls. Based on Eqs. (2)-(5), the annual mean scavenging ratio was 116,353 , and 18 for $\mathrm{SO}_{2}, \mathrm{HNO}_{3}$, and $\mathrm{NH}_{3}$, respectively. The different scavenging ratios of the three gases could be partly explained by their different solubilities. $\mathrm{HNO}_{3}$ is the most soluble species, followed by $\mathrm{NH}_{3}$, and $\mathrm{SO}_{2}$ is the least soluble gas, with a Henry's law constant of around $2.1 \times 10^{3}, 6.1 \times 10^{-1}$, and $1.2 \times 10^{-2} \mathrm{~mol} \mathrm{~m}^{-3} \mathrm{pa}^{-1}$, respectively (Sander, 2015). $\mathrm{NH}_{3}$ solubility is higher than $\mathrm{SO}_{2}$, their relative low scavenging ratio might be responsible for the short lifetime of $\mathrm{NH}_{3}$. The air pollutants incorporated into precipitation occurs at cloud level, however, the ambient concentrations were measured at the ground. Over this vertical distance, $\mathrm{NH}_{3}$ may transform into particulate $\mathrm{NH}_{4}{ }^{+}$and consequently lead to the wet scavenging mainly from particulate $\mathrm{NH}_{4}{ }^{+}$rather than gas $\mathrm{NH}_{3}$. 
Table 2. Scavenging ratios of inorganic ions and gaseous precursors on mass basis in literatures.

\begin{tabular}{|c|c|c|c|c|c|c|c|c|c|c|}
\hline \multirow{2}{*}{ Sampling site } & \multirow{2}{*}{ Period } & \multicolumn{8}{|c|}{ Scavenging ratio } & \multirow{2}{*}{ Reference } \\
\hline & & $\mathrm{W}_{\mathrm{SO}_{4}^{2-}}$ & $\mathrm{W}_{\mathrm{NO}_{3}^{-}}$ & $\mathrm{W}_{\mathrm{NH}_{4}^{+}}$ & $\mathrm{W}_{\mathrm{Cl}^{-}}$ & $\mathrm{W}_{\mathrm{K}^{+}}$ & $\mathrm{W}_{\mathrm{SO}_{2}}$ & $\mathrm{~W}_{\mathrm{HNO}_{3}}$ & $\mathrm{~W}_{\mathrm{NH}_{3}}$ & \\
\hline \multirow{5}{*}{$\begin{array}{l}\text { Wanzhou, } \\
\text { China } \\
\text { (urban) }\end{array}$} & 2015 spring & 660 & 792 & 471 & 747 & 597 & 100 & 637 & 0 & \multirow[t]{5}{*}{ This study } \\
\hline & 2015 summer & 326 & 1100 & 445 & 3532 & 355 & 40 & 373 & 34 & \\
\hline & 2015 autumn & 815 & 551 & 491 & 426 & 556 & 242 & 387 & 13 & \\
\hline & 2015 winter & 547 & 443 & 292 & 768 & 490 & 194 & 326 & 0 & \\
\hline & 2015 annual & 454 & 445 & 364 & 456 & 394 & 116 & 353 & 18 & \\
\hline $\begin{array}{l}\text { Mt. Sonnblick, } \\
\text { Europe } \\
\text { (mountain) }\end{array}$ & $\begin{array}{l}\text { Nov. } 1991- \\
\text { Nov. } 1993\end{array}$ & 1680 & 3120 & 2160 & n.a. & n.a. & n.a. & n.a. & n.a. & $\begin{array}{l}\text { Kasper-Giebl et al. } \\
\quad(1999)^{a}\end{array}$ \\
\hline $\begin{array}{l}\text { Salvatierra, } \\
\text { Spanish } \\
\text { (rural) }\end{array}$ & $\begin{array}{l}\text { Jul. 1992-Jun. } \\
1993\end{array}$ & 1000 & 3000 & 2000 & 10000 & 2000 & n.a. & n.a. & n.a. & $\begin{array}{l}\text { Encinas and Casado } \\
\text { (1999) }\end{array}$ \\
\hline $\begin{array}{l}\text { Vitoria, Spanish } \\
\text { (urban) }\end{array}$ & $\begin{array}{l}\text { Jan. } 1995- \\
\text { Dec. } 2000\end{array}$ & 2830 & 2330 & 1739 & 3030 & 1151 & n.a. & n.a. & n.a. & $\begin{array}{l}\text { Encinas et al. } \\
\qquad(2004)\end{array}$ \\
\hline $\begin{array}{l}\text { AIRMoN } 14 \\
\text { sites, U.S. }\end{array}$ & A decade & 672 & n.a. & 372 & n.a. & n.a. & n.a. & 588 & n.a. & Hicks $(2005)^{a}$ \\
\hline $\begin{array}{r}\text { Singapore } \\
\text { (urban) }\end{array}$ & $\begin{array}{l}\text { Jan.-Sep. } \\
2006\end{array}$ & 2596 & 2134 & 1660 & 2624 & 744 & n.a. & n.a. & n.a. & $\begin{array}{l}\text { He and } \\
\text { Balasubramanian } \\
(2008)\end{array}$ \\
\hline CAPMON, & between 1984 & $471-$ & $583-$ & $283-$ & $1855-$ & 497- & $125-$ & 749- & n.a. & Cheng and Zhang \\
\hline $\begin{array}{l}\text { Canada (13 } \\
\text { sites, rural) }\end{array}$ & and 2011 & 734 & 1224 & 848 & 5779 & 996 & 1339 & 5527 & & (2017) \\
\hline $\begin{array}{l}\text { Hyderabad, } \\
\text { India }\end{array}$ & Aug. 2006 & 160 & 317 & 389 & 109 & 723 & n.a. & n.a. & n.a. & $\begin{array}{l}\text { Kulshrestha et al. } \\
\text { (2009) }\end{array}$ \\
\hline Maldives & $\begin{array}{l}\text { May 2014- } \\
\text { Apr. } 2015\end{array}$ & $\begin{array}{l}203- \\
696\end{array}$ & $\begin{array}{l}1300- \\
3045\end{array}$ & $\begin{array}{l}251- \\
771\end{array}$ & $\begin{array}{l}1019- \\
3273\end{array}$ & $\begin{array}{l}554- \\
1488\end{array}$ & n.a. & n.a. & n.a. & $\begin{array}{l}\text { Budhavant et al. } \\
\qquad(2020)^{b}\end{array}$ \\
\hline $\begin{array}{l}\text { Beijing, China } \\
\text { (urban) }\end{array}$ & $\begin{array}{l}\text { Jun.-Aug. } \\
2014\end{array}$ & 312 & 420 & 168 & n.a. & n.a. & n.a. & n.a. & n.a. & Xu et al. $(2017)^{a}$ \\
\hline
\end{tabular}

n.a. no available data.

${ }^{a}$ convert to the scavenging ratio on mass basis; ${ }^{b}$ calculated scavenging ratio based on the concentrations in aerosol and precipitation.

Different seasonal patterns of the scavenging ratios were observed for different inorganic ions and gases. Seasonal variations in scavenging ratios are caused by many factors, such as ambient concentrations of the ions, rain intensities and associated precipitation chemistry and droplet spectra. These factors would affect the dissociate rate of related pollutants between ambient air and rain droplets, below-cloud evaporation of droplets, etc., all of which would contribute to the overall calculated scavenging ratio. The maximum scavenging ratio was observed in autumn for both $\mathrm{SO}_{4}{ }^{2-}$ and $\mathrm{NH}_{4}{ }^{+}$, and the minimum value appeared in summer and winter, respectively. In contrast, the highest scavenging ratio was found in summer for $\mathrm{Cl}^{-}$and $\mathrm{NO}_{3}{ }^{-}$and lowest in autumn and winter, respectively. The highest scavenging ratios of $\mathrm{SO}_{2}, \mathrm{HNO}_{3}$, and $\mathrm{NH}_{3}$ were observed in autumn, spring, and summer, respectively.

The scavenging ratio values of $\mathrm{SO}_{4}{ }^{2-}, \mathrm{NH}_{4}{ }^{+}$, and $\mathrm{K}^{+}$obtained in the present study generally agreed well with existing data reported in literature (Table 2); however, those of $\mathrm{NO}_{3}{ }^{-}$were slightly lower than reported in the other regions, which was probably related to the different size distributions among different regions, among other factors. Contrary to the predominant coarse mode distribution of $\mathrm{NO}_{3}{ }^{-}$influenced by natural sources or sea salt in other regions (Zhang et al., 2008), about $70 \%-80 \%$ of $\mathrm{NO}_{3}{ }^{-}$was found in fine mode in the study region, which might result in lower scavenging ratio since rainfall scavenges coarse particles more efficiently. Additionally, the sampling site in this study is an urban site, which is severely affected by the vehicle emissions and hence results in relatively high ambient concentrations of $\mathrm{NO}_{2}$ and $\mathrm{NO}_{3}{ }^{-}$. For the three gases, limited $\mathrm{NH}_{3}$ scavenging ratios were reported in the previous studies. The scavenging ratio of $\mathrm{SO}_{2}$ 


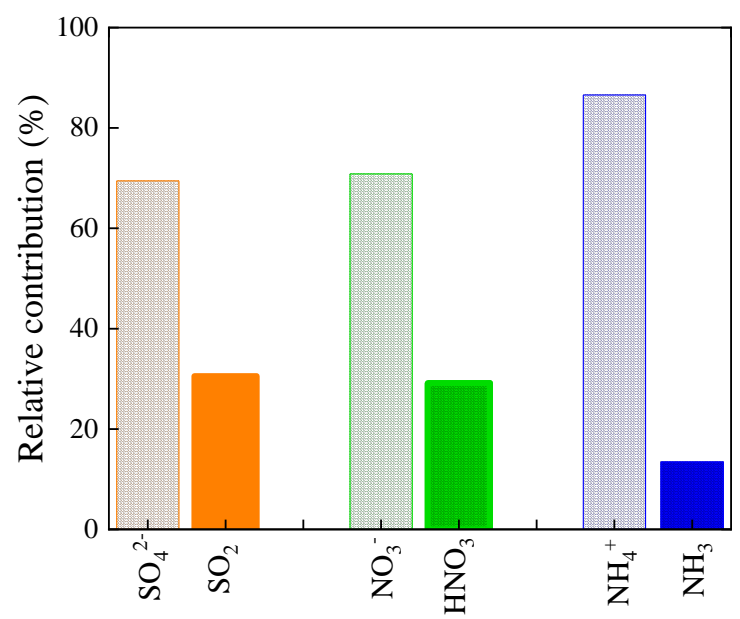

Fig. 5. Relative contributions of particulate and gas-phase to the total wet scavenging of $\mathrm{SO}_{4}{ }^{2-}$, $\mathrm{NO}_{3}{ }^{-}$, and $\mathrm{NH}_{4}{ }^{+}$during the sampling periods.

in this study was within the range of those values in the literatures, while the value for $\mathrm{HNO}_{3}$ was somewhat lower in this study (Table 2).

As expected, particulate $\mathrm{SO}_{4}{ }^{2-}$ was the dominant contributor to rainfall $\mathrm{SO}_{4}{ }^{2-}$, accounting for $69.4 \%$, while gas $\mathrm{SO}_{2}$ contributed about $30.6 \%$ (Fig. 5), which were consistent with those conducted at rural sites in Canada (Cheng and Zhang, 2017). Similar to $\mathrm{SO}_{4}{ }^{2-}$, particulate $\mathrm{NO}_{3}{ }^{-}$ accounted for about $70 \%$ of the rainfall $\mathrm{NO}_{3}{ }^{-}$, which was much higher than those reported by Cheng and Zhang (2017) (around 28\%) and Kasper-Giebl et al. (1999) (about 4-12\%). The discrepancies between our results and other literatures were probably attributed to the different characteristic of sampling location, where the sampling site with higher ambient $\mathrm{NO}_{3}{ }^{-}$ concentrations exhibited high relative contributions of particulate $\mathrm{NO}_{3}{ }^{-}$. The relative contribution of particulate $\mathrm{NH}_{4}{ }^{+}$to total wet scavenging was $86.6 \%$, which was higher than those in Cheng and Zhang (2017) (70\%) and Kasper-Giebl et al. (1999) (48-79\%).

\section{CONCLUSIONS}

Water-soluble inorganic ions in ambient fine particles and in precipitation were characterized, and relative contributions from particulate and gaseous pollutants to inorganic ions in precipitation were quantified. $\mathrm{PM}_{2.5}$ and $\mathrm{PM}_{10}$ concentrations were generally decreased after occurrence of moderate or heavy rain event, but this was not always the case after light rain event due to too many other factors affecting the ambient concentration. The scavenging ratio values derived for the five inorganic ions that were mostly distributed in fine particles varied by $25 \%$ on average, e.g., about 450 for $\mathrm{SO}_{4}{ }^{2-}, \mathrm{NO}_{3}{ }^{-}$, and $\mathrm{Cl}^{-}, 364$ for $\mathrm{NH}_{4}{ }^{+}$, and 395 for $\mathrm{K}^{+}$, likely due to their slightly different fine/coarse fractions. Scavenging ratios for gaseous species investigated here differed greatly, e.g., 353 for $\mathrm{HNO}_{3}, 116$ for $\mathrm{SO}_{2}$, and 18 for $\mathrm{NH}_{3}$, likely related to their different solubility or lifetime in air. Besides, major sources and chemical processes might have contributed to the ambient concentrations of some chemical species and thus substantially lowered the scavenging ratio, e.g., for the case of $\mathrm{NH}_{3}$. Seasonal variations of the scavenging ratios were a factor of 1.7-8 for different air pollutants. Wet scavenging of $\mathrm{SO}_{4}{ }^{2-}, \mathrm{NO}_{3}{ }^{-}$, and $\mathrm{NH}_{4}{ }^{+}$ were primarily from particulate forms (>69\%), especially considering that only fine particles were considered in this estimation due to the lack of the coarse particles data. The scavenging ratio data obtained in this study may be used for improving the prediction of particle concentrations during rain periods using air quality models.

\section{ACKNOWLEDGEMENTS}

This work was supported by the National Natural Science Foundation of China (grant numbers 
41405027, 41831285), Key Research and Development Projects of Sichuan Province (grant number 2020YFS0056), and the National Key R\&D Program of China (grant numbers 2016YFC0200400, 2018YFC0214002).

\section{SUPPLEMENTARY MATERIAL}

Supplementary data associated with this article can be found in the online version at https://doi.org/10.4209/aaqr.200513

\section{REFERENCES}

Aikawa, M., Hiraki, T. (2009). Washout/rainout contribution in wet deposition estimated by $0.5 \mathrm{~mm}$ precipitation sampling/analysis. Atmos. Environ. 43, 4935-4939. https://doi.org/10.1016/j.at mosenv.2009.07.057

Aikawa, M., Kajino, M., Hiraki, T., Mukai, H. (2014). The contribution of site to washout and rainout: Precipitation chemistry based on sample analysis from $0.5 \mathrm{~mm}$ precipitation increments and numerical simulation. Atmos. Environ. 95, 165-174. https://doi.org/10.1016/j.atmosenv.2014. 06.015

Budhavant, K., Andersson, A., Holmstrand, H., Bikkina, P., Bikkina, S., Satheesh, S.K., Gustafsson, O. (2020). Enhanced light-absorption of black carbon in rainwater compared with aerosols over the northern Indian Ocean. J. Geophys. Res. 125, e2019JD031246. https://doi.org/10.1029/20 19JD031246

Cheng, I., Zhang, L. (2017). Long-term air concentrations, wet deposition, and scavenging ratios of inorganilc ions, $\mathrm{HNO}_{3}$, and $\mathrm{SO}_{2}$ and assessment of aerosol and precipitation acidity at Canadian rural locations. Atmos. Chem. Phys. 17, 4711-4730. https://doi.org/10.5194/acp-174711-2017

Encinas, D., Casado, H. (1999). Rain-Aerosol coupling in a rural area in the Basque Country (Spain): Scavenging ratios. Aerosol Sci. Technol. 30, 411-419. https://doi.org/10.1080/027868299304 462

Encinas, D., Calzada, I., Casado, H. (2004). Scavenging ratios in an urban area in the Spanish Basque Country. Aerosol Sci. Technol. 38, 685-691. https://doi.org/10.1080/02786820490460716

Engelmann, R.J. (1971). Scavenging prediction using ratios of concentrations in air and precipitation. J. Appl. Meteorol. 10, 493-497. https://doi.org/10.1175/1520-0450(1971)0102.0.CO;2

Gao, B., Ouyang, W., Cheng, H.G., Xu, Y., Lin, C.Y., Chen, J. (2019). Interactions between rainfall and fine particulate matter investigated by simultaneous chemical composition measurements in downtown Beijing. Atmos. Environ. 218, 117000. https://doi.org/10.1016/j.atmosenv.2019. 117000

Ge, B.Z., Wang, Z.F., Gbaguidi, A.E., Zhang, Q.X. (2016). Source Identification of acid rain arising over northeast China: Observed evidence and model simulation. Aerosol Air Qual Res. 16, 1366-1377. https://doi.org/10.4209/aaqr.2015.05.0294

Han, Y., Xu, H., Bi, X.H., Lin, F.M., Jiao, L., Zhang, Y.F., Feng, Y.C. (2019). The effect of atmospheric particulates on the rainwater chemistry in the Yangtze River Delta, China. J Air Waste Manage. 69, 1452-1466. https://doi.org/10.1080/10962247.2019.1674750

He, J., Balasubramanian, R. (2008). Rain-aerosol coupling in the tropical atmosphere of southeast Asia: Distribution and scavenging ratios of major ionic species. J. Atmos. Chem. 60, 205-220. https://doi.org/10.1007/s10874-008-9118-x

Hicks, B.B. (2005). A climatology of wet deposition scavenging ratios for the United States. Atmos. Environ. 39, 1585-1596. https://doi.org/10.1016/j.atmosenv.2004.10.039

Kajino, M., Aikawa, M. (2015). A model validation study of the washout/rainout contribution of sulfate and nitrate in wet deposition compared with precipitation chemistry data in Japan. Atmos. Environ. 117, 124-134. https://doi.org/10.1016/j.atmosenv.2015.06.042

Kasper-Giebl, A., Kalina, M.F., Puxbaum, H. (1999). Scavenging ratios for sulfate, ammonium and nitrate determined at Mt. Sonnblick (3106 M Asl). Atmos. Environ. 33, 895-906. https://doi.org/ 10.1016/S1352-2310(98)00279-9 
Kulshrestha, U.C., Reddy, L.A.K., Satyanarayana, J., Kulshrestha, M.J. (2009). Real-time wet scavenging of major chemical constituents of aerosols and role of rain intensity in Indian Region. Atmos. Environ. 43, 5123-5127. https://doi.org/10.1016/j.atmosenv.2009.07.025

Li, Q.K., Yang, Z., Li, X.D., Ding, S.Y., Du, F. (2019a). Seasonal characteristics of sulfate and nitrate in size-segregated particles in ammonia-poor and -rich atmospheres in Chengdu, Southwest China. Aerosol Air Qual Res. 19, 2697-2706. https://doi.org/10.4209/aaqr.2019.07.0368

Li, R., Cui, L.L., Zhao, Y.L., Zhang, Z.Y., Sun, T.M., Li, J.L., Zhou, W.H., Meng, Y., Huang, K., Fu, H.B. (2019b). Wet deposition of inorganic ions in 320 cities across China: Spatio-temporal variation, source apportionment, and dominant factors. Atmos. Chem. Phys. 19, 11043-11070. https://doi.org/10.5194/acp-19-11043-2019

Li, Y.P., Hao, Q.J., Wen, T.X., Ji, D.S., Liu, Z.R., Wang, Y.S., Jiang, C.S. (2018a). Mass concentrations and size distributions of water-soluble inorganic ions in atmospheric aerosols in Beibei district, Chongqing. Huan Jing Ke Xue. 39, 4002-4013. https://doi.org/10.13227/j.hjkx.201712077

Li, Y.P., Hao, Q.J., Wen, T.X., Ji, D.S., Liu, Z.R., Wang, Y.S., Li, X.X., He, X.H., Jiang, C.S. (2018b). Pollution characteristics of water-soluble ions in aerosols in the urban area in Beibei of Chongqing. Aerosol Air Qual Res. 18, 1531-1544. https://doi.org/10.4209/aaqr.2017.11.0500

Lu, X.C., Fung, J.C.H. (2018). Sensitivity assessment of $\mathrm{PM}_{2.5}$ simulation to the below-cloud washout schemes in an atmospheric chemical transport model, Tellus B70, 1476435. https://doi.org/10.1080/16000889.2018.1476435

Lu, X.C., Chan, S.C., Fung, J.C.H., Lau, A.K.H. (2019). To what extent can the below-cloud washout effect influence the $\mathrm{PM}_{2.5}$ ? A combined observational and modeling study. Environ Pollut. 251, 338-343. https://doi.org/10.1016/j.envpol.2019.04.061

Luan, T., Guo, X.L., Zhang, T.H., Guo, L.J. (2019). Below-Cloud aerosol scavenging by differentintensity rains in Beijing City. J. Meteorol. Res. 33, 126-137. https://doi.org/10.1007/s13351019-8079-0

Olszowski, T. (2016). Changes in $\mathrm{PM}_{10}$ concentration due to large-scale rainfall. Arabian J. Geosci. 9, 160. https://doi.org/10.1007/s12517-015-2163-2

Sander, R. (2015). Compilation of Henry's law constants (version 4.0) for water as solvent. Atmos. Chem. Phys. 15, 4399-4981. https://doi.org/10.5194/acp-15-4399-2015

Wang, H.B., Yang, F.M., Shi, G.M., Tian, M., Zhang, L.M., Zhang, L.Y., Fu, C.A. (2016). Ambient concentration and dry deposition of major inorganic nitrogen species at two urban sites in Sichuan Basin, China. Environ Pollut. 219, 235-244. https://doi.org/10.1016/j.envpol.2016.10. 016

Wang, H.B., Shi, G.M., Tian, M., Chen, Y., Qiao, B.Q., Zhang, L.Y., Yang, F.M., Zhang, L.M., Luo, Q. (2018a). Wet deposition and sources of inorganic nitrogen in the Three Gorges Reservoir Region, China. Environ Pollut. 233, 520-528. https://doi.org/10.1016/j.envpol.2017.10.085

Wang, H.B., Tian, M., Chen, Y., Shi, G.M., Liu, Y., Yang, F.M., Zhang, L.M., Deng, L.Q., Yu, J., Peng, C., Cao, X.Y. (2018b). Seasonal characteristics, formation mechanisms and source origins of $\mathrm{PM}_{2.5}$ in two megacities in Sichuan Basin, China. Atmos. Chem. Phys. 18, 865-881. https://doi.org/10.5194/acp-18-865-2018

Wang, X., Zhang, L., Moran, M.D. (2010). Uncertainty assessment of current size-resolved parameterizations for below-cloud particle scavenging by rain. Atmos. Chem. Phys. 10, 56855705. https://doi.org/10.5194/acp-10-5685-2010

Xu, D.H., Ge, B.Z., Wang, Z.F., Sun, Y.L., Chen, Y., Ji, D.S., Yang, T., Ma, Z.Q., Cheng, N.L., Hao, J.Q., Yao, X.F. (2017). Below-cloud wet scavenging of soluble inorganic ions by rain in Beijing During the summer of 2014. Environ Pollut. 230, 963-973. https://doi.org/10.1016/j.envpol.2017.07.033

Zhang, L., Michelangeli, D.V., Taylor, P.A. (2004). Numerical studies of aerosol scavenging in lowlevel, warm stratiform clouds and precipitation. Atmos. Environ. 38, 4653-4665. https://doi.org/10.1016/j.atmosenv.2004.05.042

Zhang, L., Vet, R. (2006). A review of current knowledge concerning size-dependent aerosol removal. China Particuology. 4, 272-282. https://doi.org/ 10.1016/S1672-2515(07)60276-0

Zhang, L., Vet, R., Wiebe, A., Mihele, C., Sukloff, B., Chan, E., Moran, M.D., Iqbal, S. (2008). Characterization of the size-segregated water-soluble inorganic ions at eight canadian rural sites. Atmos. Chem. Phys. 8, 7133-7151. https://doi.org/10.5194/acp-8-7133-2008 